\title{
Forest Conservation and Utilization in Embobut, Cherangani Hills, Kenya
}

\author{
Brian Rotich \\ Department of Environment and Resources Development, Chuka University, Chuka, Kenya \\ Email address: \\ brotich@chuka.ac.ke \\ To cite this article: \\ Brian Rotich. Forest Conservation and Utilization in Embobut, Cherangani Hills, Kenya. International Journal of Natural Resource Ecology \\ and Management. Vol. 4, No. 1, 2019, pp. 7-13. doi: 10.11648/j.jinrem.20190401.12
}

Received: January 1, 2019; Accepted: January 15, 2019; Published: January 31, 2019

\begin{abstract}
Embobut forest is a constituent block of the Cherangani hills ecosystem, which entails the five major water towers in Kenya and home to the indigenous hunters and gatherers-the Cherangany/Sengwer community. This study aimed at investigating forest utilization and conservation in Embobut, Cherangani hills in the western part of Kenya. Data was collected using questionnaires, Focus Group Discussions (FGDs) and Key Informant Interviews (KII) and analysis done using Microsoft office excel 2013. A total of 42 respondents living inside and within a radius of 5 Kilometers from the forest were sampled for the study. Research findings indicated that $95.2 \%$ of the respondents benefited from the forest with fuel wood being the most harvested forest product $(71.4 \%)$. Honey $(26.2 \%)$ and herbal medicine $(21.4 \%)$ were the second and third most harvested products from the forest. Other benefits and products obtained from the forest included grazing, building poles, wild fruits, and bush meat. Despite the conservation efforts by community members and the Kenya Forest Service (KFS), a number of conservation challenges existed in the study area including illegal grazing, illegal logging, charcoal burning, forest fires and encroachment into the forest. The researcher therefore recommends the Implementation of the Cherangani hills Forest Strategic Management Plan (2015-2040) to address the existing challenges. Integration of the indigenous communities into the political processes especially around land-use issues and forest management will also be critical to ensuring their future wellbeing while concurrently achieving conservation goals.
\end{abstract}

Keywords: Embobut, Conservation, Cherangani Hills, Indigenous People

\section{Introduction}

Forests cover a third of the earth's surface and provides a number of significant economic, social and environmental values. It is estimated that about 1.6 billion people including the indigenous people, rural communities, smallholder farmers and employees of forest-based enterprises are dependent on forests [1]. Forests also comprises $22.2 \%$ of household incomes in developing countries with the main forest products contributing to incomes being fuel wood, building poles, timber and building materials. Households also use a variety of non-timber forest products that contribute to food security, welfare, medicinal needs, and cultural practices [2]. In Kenya, forests are one of the most important national assets in terms of economic, environmental, social and cultural values. It is estimated that the forest sector provides employment to over 50,000 people directly and other 300,000 indirectly and more than 530,000 households living within a radius of 5 kilometers from the forest reserves depend on forest for cultivating, grazing, fishing, fuel food, honey, herbal medicine, water and other benefits [3].

There has been a general increase in the utilization of forest resources globally due to rapid population growth and in some instances the demand has exceeded the ecosystem capacity to supply thereby putting pressure on the ecosystems and threatening their sustainability. The food and Agricultural Organization of the United Nations (FAO), estimates that about 129 million hectares of forests have been lost between 1990 and 2015. There has however been a reduction in the net annual forest loss rate from 0.18 percent in the early 90 s to 0.08 percent during the period of 2010-2015 due to improved management and increased conservation efforts [4]. Different management approaches have been employed worldwide in the conservation and management of forest resources with the major approaches being state management, joint management by the state and communities and exclusive community based 
forest management. There has been a fundamental shift since the 80's in approaches to forest management and conservation from state agencies to a more participatory approach in an effort to balance the social, environmental and economic objectives [5]. The poor outcomes of state natural resource management strategies and planned development is what forced policy makers and scholars to reconsider the role of communities in resource use and conservation [6]. Community forest management has been the preferred option in most developing countries for reducing deforestation while at the same time improving the welfare of rural communities [7].

Globally, forest policies are increasingly focused on strengthening the tenure rights of people living in and around forests. Research into forest management has continuously highlighted the effectiveness of collaborative institutions. This is slowly being put into practice, with great benefits to communities and marginal groups [8]. The indigenous people form majority of the marginal groups. Areas of natural forest under the ownership and administration of indigenous people and traditional communities is estimated at over 120 million hectares and probably greater as not all forest areas under the indigenous communities are recognized. These groups greatly depend on the forests for their livelihoods and usually have a strong attachment to the forest landscapes. Despite forests forming the basis for survival for many indigenous people their traditional tenure systems are not always recognized, which can leave Indigenous forest people without rights and access to the forests on which their livelihoods depend $[9,10]$.

The study sought to answer three research questions namely; what products does the community derive from the forest, what conservation efforts are currently in place in Embobut and what forest conservation challenges exist in Embobut.

\section{Description of Study Area and Methodology}

\subsection{Description of Study Area}

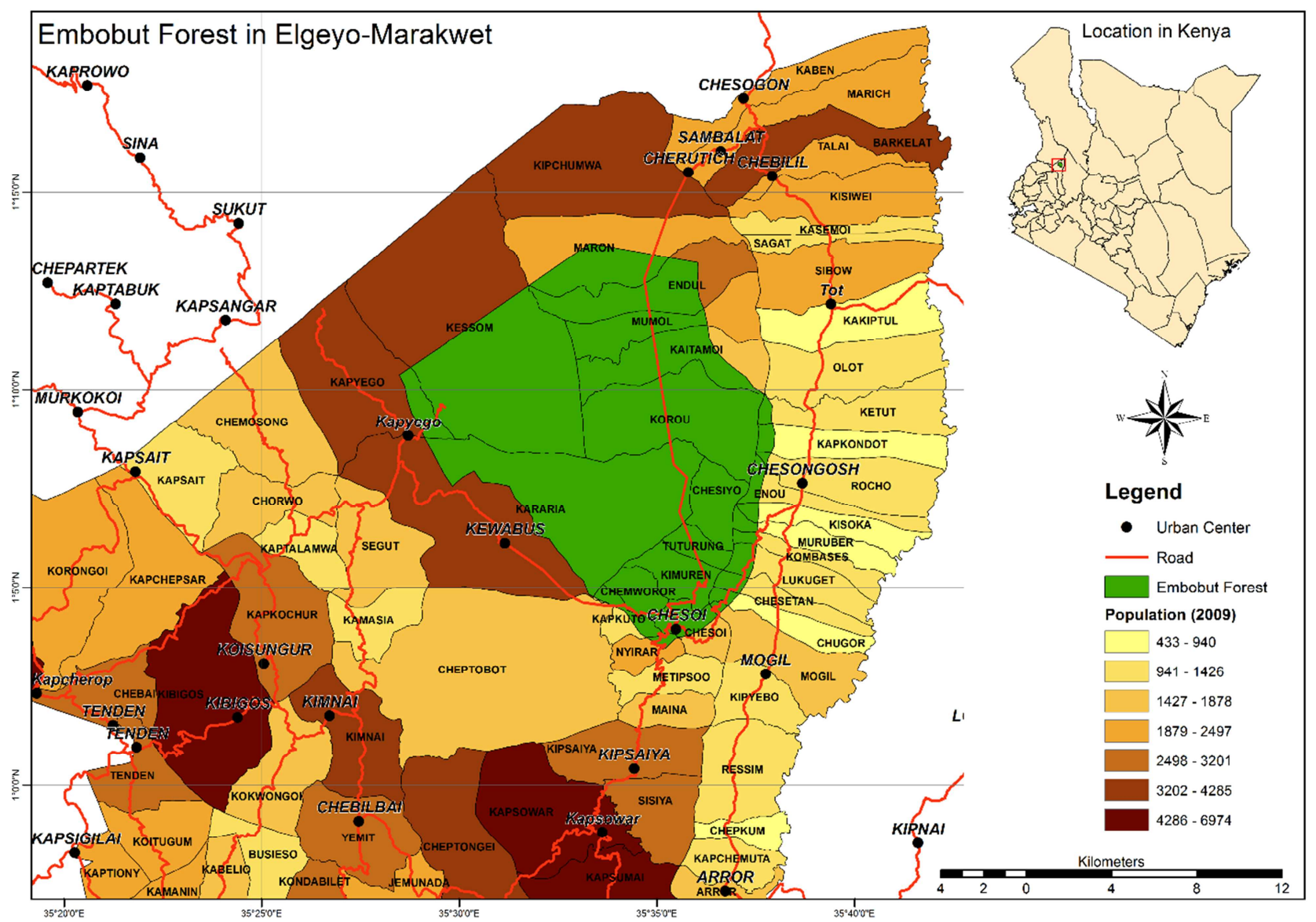

Figure 1. Map of the study area (Source: Author).

Embobut is an indigenous forest reserve in Elgeyo Marakwet County, Kenya with an area of 21,933 Ha [11]. It is one of the 12 blocks of the Cherangani hills gazetted under legal notice number 26 of $6^{\text {th }}$ November 1954 . The forest lies at Latitude $1^{\circ} 15^{\prime} 0$ "and Longitude $35^{\circ} 34^{\prime} 59.98^{\prime \prime}$ (Figure. 1). It is a subtropical dry forest with an average elevation of 1,928 meters above sea level. Embobut Forest has a humid climate with average annual rainfall of $1200 \mathrm{~mm}$. The rainy seasons are from April to August and dry season from December to February. The Cherangani hills area has mainly moderately deep soils of good structure and high organic matter content and variable acidity [11]. The Kalenjin tribes are the 
dominant ethnic group living in and around Embobut forest.

\subsection{Methodology}

This study was conducted between the months of January and March 2017, where community members living inside and within the radius of $5 \mathrm{~km}$ from the forest edge formed the target population as they were presumed to be the primary beneficiaries from the forest. A total 42 household heads from Korou and Chesoi sub-locations (see figure.1 above) formed the sample size for the forest community population which was estimated at around 420 households. The two locations which formed the study sites were specifically selected to represent populations living around and inside the forest respectively. Descriptive statistics was used for this study as data collection was done by means of structured questionnaires, Key Informant Interviews, and Focus Group Discussion. The questionnaires primarily focused on collecting data on benefits obtained by community members from the forest, various conservation efforts and conservation challenges. FGDs was conducted using semi-structured guidelines with groups of pre-selected respondents based on their gender, age, availability and willingness to participate. There were three groups made of the youth, men and women each consisting of 8 participants. Out of the total participants (13) were males while (11) were females.

A total of five key informants interviews were carried out. The key informants forest officers (2) Community Based Organization (CBO) leader (1), and Community Forest Association officials (2). The collected data was then analyzed using Microsoft excel 2013 and results presented in form of tables and graphs.

\section{Results and Discussion}

\subsection{Socioeconomic Characteristics of the Respondents}

The socio economic characteristics of the respondents are summarized in table 1 below.

Table 1. Socio economic characteristics of the respondents.

\begin{tabular}{lll}
\hline Socio economic characteristics & Frequency $(\mathbf{n = 4 2})$ & Percentage (\%) \\
\hline Gender & 29 & 69 \\
Male & 13 & 31 \\
Female & & \\
Age & 9 & 21.4 \\
$18-25$ & 7 & 16.7 \\
$26-35$ & 16 & 38.1 \\
$36-45$ & 3 & 7.2 \\
$46-55$ & 7 & 16.7 \\
$>55$ & & \\
Education level & 6 & 14.3 \\
No formal education & 10 & 23.8 \\
Primary & 14 & 33.3 \\
Secondary & 12 & 28.6 \\
Tertiary & & \\
Occupation of the respondents & 15 & 35.7 \\
Farmer & 8 & 19.0 \\
Casual laborer & 5 & 11.9 \\
Hunter and gatherer & 7 & 16.7 \\
Civil servants & & \\
\hline
\end{tabular}

\begin{tabular}{lll}
\hline Socio economic characteristics & Frequency $(\mathbf{n = 4 2 )}$ & Percentage (\%) \\
\hline Students & 5 & 11.9 \\
Others & 2 & 4.76 \\
Ethnic group & & \\
Marakwet & 18 & 42.9 \\
Cherangany/Sengwer & 16 & 38.1 \\
Keiyo & 3 & 7.1 \\
Others & 5 & 12 \\
\hline
\end{tabular}

There were more male respondents $(69 \%)$ than the female respondents $(31 \%)$. This can be attributed to the Kalenjin traditions and customs where males are the household heads and the females can only attain this status in the case of bereavement or the absence of the males. Most of the respondents were from the larger Kalenjin tribe as the forest is located in the rift valley of Kenya. Examination of the individual ethnic groups revealed that the Marakwet and Cherangany/ Sengwer were the dominant Kalenjin sub tribes. The Sengwer (also known as Cherangany) is an ethnic minority hunter-gatherer indigenous community living along the slopes of Cherangany Hills and distributed in three administrative Counties of Elgeiyo-Marakwet, Trans-Nzoia and West Pokot. Their current population is about 30,000 with their livelihood, health system and culture depending on the natural resources found in the forests [12]. Findings from the study indicate a gradual shift in lifestyles from hunting and gathering to farming (mixed and crop) among the community members with majority of the respondents (35.7\%) practicing farming while $(11.9 \%)$ still hunt and gather. Most of the respondents had attained secondary $(33.3 \%)$ and tertiary education $(28.6 \%)$ with $23.8 \%$ having attained basic primary education. There was however a fraction of the respondents $(14.3 \%)$ who were illiterate as they didn't have any formal education. The youth within age bracket of between 18-35 years and those between 36-45 years comprised majority of the respondents (38.1\%). About $16.7 \%$ of the respondents were above 55 years. The age bracket with the least respondents was 46-55. The age structure of a given population determines the intensity and quantity of forest resources harvested. The youth for instance are involved more in firewood collection, harvesting building poles and charcoal burning. They are also vital in realizing conservation goals as they readily provide cheap labor and in some instance volunteer to assist the authorities in conservation practices like reforestation.

\subsection{Benefits and Products Obtained from the Forest}

Most of the respondents $(95.2 \%)$ benefited or obtained multiple products from the forest. Firewood was the most harvested forest product $(71.4 \%)$. Other products harvested from the forest included honey $(26.2 \%)$, herbal medicine $(21.4 \%)$, grazing $(14.3 \%)$, timber $(16.7 \%)$, building poles $(21.4 \%)$, wild fruits $(23.8 \%)$, and bush meat $(7.1 \%)$. The forest was also important for spiritual and cultural anchorage. Figure 2 below gives a graphical summary of the benefits and products obtained from Embobut forest. 


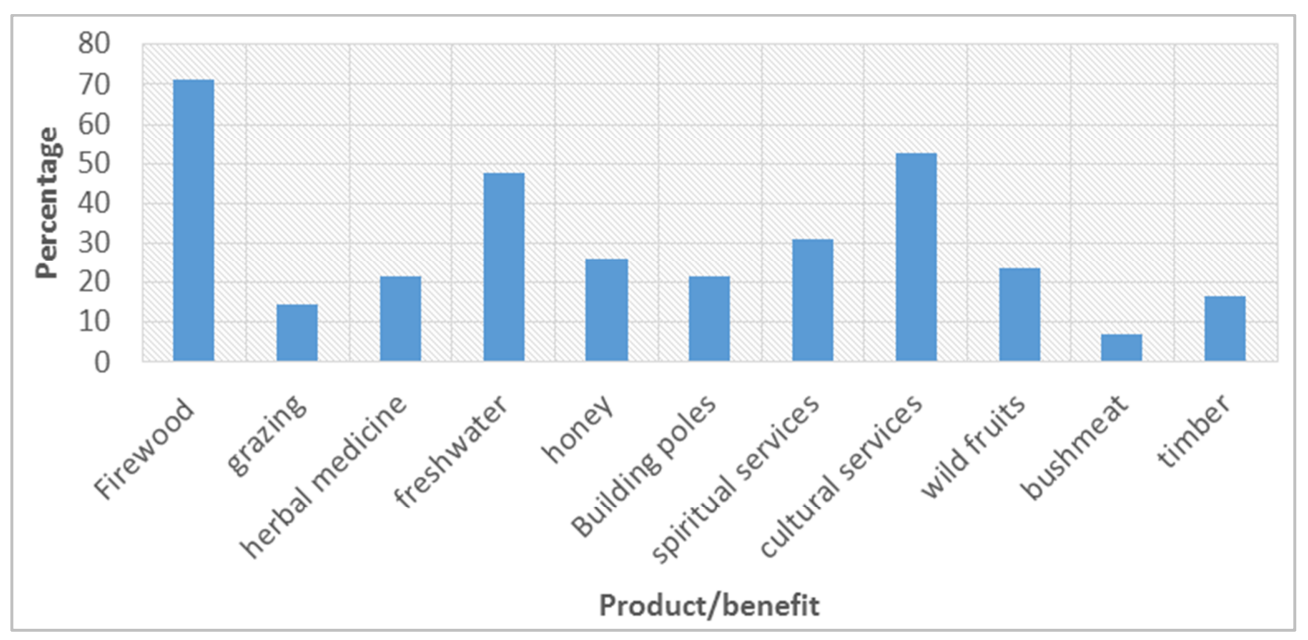

Figure 2. Benefits and products obtained from Embobut forest.

The residents indicated that they were required to pay 120 Kenyan shillings permit fees per month to the KFS in order to be eligible for firewood collection from the forest for a period not exceeding one month. Fuel wood is the main source of energy in the continent of Africa as it is the most affordable source of energy for cooking and heating, accounting for almost $90 \%$ of primary energy consumption in most parts of Africa [13]. Githiomi [14], further established that firewood is the main source of energy in Kenya providing for $70 \%$ of Kenya's total national energy needs primarily as fuel for household cooking and also an important energy source for small-scale rural industries. Langat et al. [15] conducted a similar study in Mau forest, Kenya and report primary dependence by forest communities on forest resources for subsistence and occasionally for sale with fuel wood being the highest contributor to household forest income. Up to $80 \%$ of people in developing countries still rely on traditional medicines with almost half of these substances originating from plants and trees in tropical forests [16]. The medicine men/women revealed they have a systematic way of harvesting herbal medicine from the various sections of the forest to avoid overharvesting and the extinction of vital medicinal plant species. Honey was harvested particularly by the Cherangany/Sengwer community as their traditional economy was based on beekeeping, hunting and gathering. A study by There has however been a decline in the quantity and quality of honey harvested from the forest partly due to deforestation which has led to the reduction in flora biodiversity and abundance. The forest was important for cultural and spiritual anchorage; providing a site for traditional circumcision ceremonies of teenage boys, shrines for sacrifices and offerings to the ancestors and site for rain making rituals. The forest also had ecological significance as it was source of fresh water from rivers Embobut and Aror.

\subsection{Forest Management and Conservation Practices}

Embobut forest is jointly managed by the KFS and local communities. There are two forest stations (Chesoi and
Kapyego) which serve as administrative centers under the supervision of an Ecosystem Conservator based in Iten town that in turn reports to the head of conservancy North Rift Conservancy based in Eldoret. Additionally there is a Zonal Forest Manager based at Kapsowar tasked with the administration of Marakwet Sub-county forests on behalf of the Ecosystem Conservator. There were two registered CFAs in the study area as of the period the study was being conducted. Community Forest Management (CFM) is a widely adopted forest conservation approach in the tropics, however, there is weak evidence on its performance in some countries [17]. Community members were involved in various forest conservation practices as shown in Table 2 below.

Table 2. Forest conservation practices.

\begin{tabular}{lll}
\hline Conservation practice & Frequency (n) & Percentage (\%) \\
\hline Reforestation & 17 & 40.5 \\
Afforestation & 14 & 33.3 \\
Farm Forestry & 8 & 19.1 \\
Monitoring & 7 & 16.7 \\
Tree nursery establishment & 5 & 11.9 \\
\hline
\end{tabular}

Reforestation and afforestation was primarily done by community members with support from the Kenya Forest service, environmental Non-Governmental Organizations (Nature Kenya and local CBOs (Sengwer Initiative Forum) who were the chief suppliers of the tree seedlings and in some instance provided financial support for tree planting in an otherwise voluntary exercise. Agroforestry was also practiced in the study area with home gardens and boundary planting systems being the dominant agroforestry practices. Though agroforestry adoption was still low, the agroforestry practices helped reduce the pressure on the natural forest as most products (fuel wood, timber, fodder and poles) could be sourced from the agroforestry trees at the farm. Community members also participated in monitoring of the forest through the local CFAs as scouts and forest guards. Prasad et al., [18], reiterates the significance of forest protection and enforcement of rules as key factors for the improvement of 
forest condition.

A few individual community members and groups had established tree nurseries for commercial purposes thereby providing readily available seedlings for reforestation. They however cited challenges in obtaining seeds especially for the indigenous tree species for nursery establishment.

The use of the forest for customary and spiritual purposes also aided in forest conservation as these practices form a significant component of indigenous environmental management systems. These natural sacred sites typically exhibit richness in biodiversity as they are usually protected from destruction by successive community generations thereby promoting conservation.

\subsection{Forest Conservation Challenges}

More than three quarters $(90.2 \%)$ of the respondents acknowledged challenges in forest conservation. The five major challenges were illegal grazing $(54.8 \%)$, encroachment into the forest for agricultural practices (26.2\%), illegal logging $(21.4 \%)$ charcoal production $(21.4 \%)$ and forest fires $(9.5 \%)$ as shown in figure 3 below.

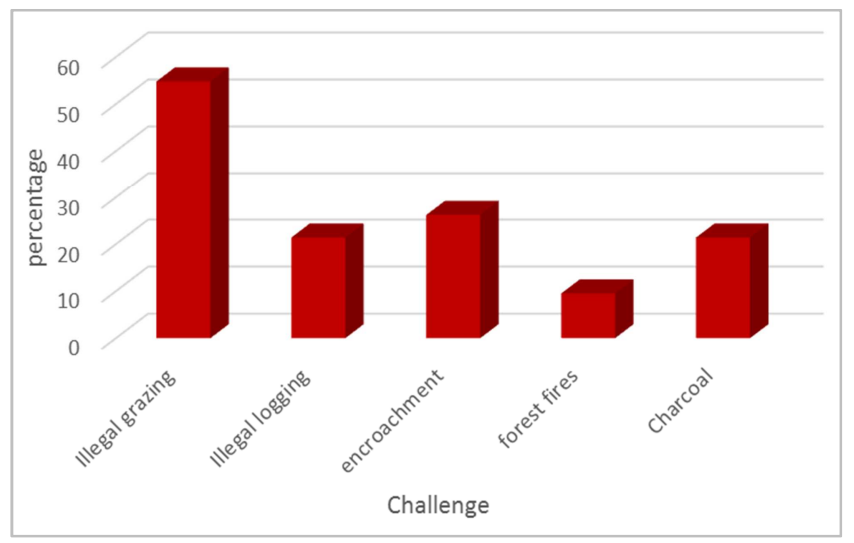

Figure 3. Forest conservation challenges.

The government of Kenya [19], notes that illegal grazing and encroachment into the forest for agricultural purposes are the major challenges of forest conservation in the Kenya. Illegal grazing was a notable challenge in the study area though seasonal. Grazing is allowed by the forest management upon the payment of 30 Kenyan Shillings per month, per livestock head for a grazing permit. The residents however reported cases of livestock grazing in the forest by non-community members from neighboring counties especially during the dry seasons without authorization/permits. This resulted in the clearing of the ground vegetation and in some incidences the branches from the forest trees are cut down for pasture. The situation is further exacerbated by overstocking where large herds of cattle are driven into the forest and allowed to roam leading to forest degradation and loss of its ecosystem functions. Encroachment into the forest by non-residents and a few locals for agricultural purposes was also another notable conservation challenge. In the past two decades, Kenya has experienced significant losses in forest cover mainly due to agricultural expansion and population growth with large areas of forested lands being cleared for agriculture and settlements purposes. The Illegal logging for timber and other wood forest products (posts and poles) was common in the study area as an income generating activity. A similar study by Mamo et al. [20] In Dendi district, Ethiopia revealed a high dependence by poor local forest communities on forest resources for income generation. Respondents cited graft as the leading contributing factor in illegal logging as some corrupt forest officials in fact facilitate the exercise as they received bribes to allow illegal logging. Ochieng [21], discloses that illegal logging and overharvesting of forest products and encroachment are the major causes of natural forests degradation and eventually deforestation in the Kenya. Technological innovation has led to the development of high-tech logging and sawing equipment which promotes clearing of forests at rates much greater that their replacement. Natural forest fires and those started by honey collectors and charcoal burners are also common especially during the dry seasons. Illegal charcoal production for commercial purposes was another conservation problem as some residents and migrants relied on the sale of charcoal for their livelihoods.

The FGDs revealed lack of full inclusion of the community members in forest management and conservation. Despite having CFAs in the study area, the state has failed to fully engage the local community in forest management decision making, equity in sharing of accruing benefits and recognition of tenure rights in relation to forest utilization. Ngendakumana et al., [22] points out a growing consensus among contemporary scholars that adequate forest tenure and resource rights of local populations are a pre requisite for conservation of biodiversity and sustainable development.

Globally, there has been a great emphasis on the inclusion of indigenous communities in environmental conservation due to their vast knowledge of their landscapes. The role of indigenous communities in environmental management and development in relation to their knowledge and traditional practices is further recognized in Principle 22 of the Rio declaration on environment which asserts that states should recognize and duly support the identity, culture and interests of indigenous communities and enable their effective participation in conservation for the achievement of sustainable development [23].

Embobut forest being a home to the indigenous Sengwer/Cherangany community has a long-standing history of forceful evictions dating back to the year 1895 when Kenya became a British colony. Local community members were then evicted and displaced to settle white farmers and for conservation purposes and since then a series of evictions ensued, the latest occurring in 2015. Community members and especially the indigenous population feel that the government has failed to recognize their traditional conservation practices and customary rights to land ownership and forest use and instead labelled them squatters. KFS on the other hand views the community members living within the forest boundaries as squatters and a threat to the 
forest hence the continued eviction efforts. These conflicts often have serious conservation implications as in the case of the suspension of a Kshs 3.8 billion European Union funded water conservation project in the Cherangani hills ecosystem in the year 2018 following reports of forceful evictions and lack of inclusion of the indigenous Cherangany/Sengwer community in the project. Most International funding organizations value indigenous forest communities' rights as they support states in their bid to conserve forest resources [24].

There have been some concerted efforts by the government under the ministry of Environment and Natural Resources with support from the World Bank to dialogue with forest community members in a bid to harmonize conservation and community forest utilization with a conclusive outcome yet to be achieved.

\section{Conclusion}

It is evident from the study that the forest community members are dependent on the forest for direct and indirect benefits despite the various challenges facing forest conservation. There is therefore a need for the development of alternative sources of livelihoods by community members to ease pressure on natural forests and poverty alleviation through enhancement of Income Generating Activities (IGAs) as past studies has shown higher reliance on forest resources by poor households. The impact of migrant forest users (especially the pastoralists) on the resource base via grazing specifically during the dry seasons is significant hence the need for their incorporation into the community community-based forest management efforts. Political goodwill spells hope in increasing the forest cover in the study area and the nation as a whole though afforestation and reforestation programmes, after the nationwide tree planting campaign was launched mid 2018 by the national government. The campaign aims at mobilizing mass tree planting by citizens to in a bid to achieve the $10 \%$ tree cover in the country as stipulated in the constitution of Kenya and mitigate the impacts of climate change witnessed in the country as a result of forest degradation.

Despite community involvement in the joint management of the forest though the CFAs, full inclusivity of indigenous communities in conservation and management is yet to be achieved via equity in benefit sharing with the community members, decision making and recognition of tenure rights . Recognition, documentation and incorporation of the existing indigenous knowledge and conservation practices into the mainstream conservation laws and policies by KFS is essential for better management outcomes. The national government should ensure ancestral forest community's rights are respected and continuing efforts to integrate rainforest people into the political process, especially around land-use issues, will be critical to ensuring their future wellbeing.

Finally there is need for the implementation of the Cherangani Hill Forest Strategic Management Plan of 2015-
2040 and further research be done on the impacts of changing community lifestyle on forest conservation.

\section{Acknowledgements}

The author is thankful to residents of Embobut and officials from the Kenya Forest Service for their input and assistance during data collection.

\section{References}

[1] Chao, S. (2012) Forest peoples: numbers across the world, Forest Peoples Programme, Moreton-in-Marsh, UK. Retrieved on $10 / 11 / 2017$ from

http://www.forestpeoples.org/topics/climateforests/publication/2 012/new-publication-forest-peoples-numbersacross-world.

[2] Angelsen, A., Jagger, P., Babigumira, R., Belcher, B., Hogarth, N. J., Bauch, S., Wunder, S. (2014). Environmental income and rural livelihoods: a global-comparative analysis. World Development, 64, S12-S28.

[3] Kenya Forest Service, (2017). History of forestry in Kenya. Retrieved on 28/05/2018 from

http://www.kenyaforestservice.org/index.php/about-kfs/historyof-forestry-in-kenya.

[4] FAO, (2015). Global Forest Resources Assessment 2015. Retrieved on 11/11/2017 from http://www.fao.org/3/ai4808e.pdf.

[5] Banerjee, A., Campbell, G., Cruz, M., Davis, S. and Molnar, A. (1995). Participation in Forest and Conservation Management.

[6] Agrawal, A. and Gibson, C. C. (1999), "Enchantment and Disenchantment: The Role of Community in Natural Resource Conservation", World Development, Vol.27, No.4, pp.629-649.

[7] Santika, T., Meijaard, E., Budiharta, S., Law, E. A., Kusworo, A., Hutabarat, J. A., ... Wilson, K. A. (2017). Community forest management in Indonesia: Avoided deforestation in the context of anthropogenic and climate complexities. Global Environmental Change, 46 (December 2016), 60-71. https://doi.org/10.1016/j.gloenvcha.2017.08.002.

[8] CIFOR. (2017). Forest Policy. Retrieved on 11/11/2017 from http://www.cifor.org/forest-policy/.

[9] Molnar, A., Scherr, S. and Khare, A. (2004). Who conserves the world's forests? Community driven strategies to protect forests and respect rights, Washington, DC, Forest Trends.

[10] UNEP, FAO, \& UNFF. (2009). Vital Forest Graphics: Stopping the Downswing? UNEP/Grid-Arendal. Retrieved on 18/11/2017 from https://www.cbd.int/doc/meetings/for/wscb-fbdcc01/other/wscb-fbdcc-01-oth-13-en.pdf.

[11] Kenya Forest Service (2015). Cherangani Hills Forest strategic Ecosystem Management Plan, 2015-2040. Retrieved on $11 / 01 / 2019$ from https://www.researchgate.net/publication/284166727_Cheranga ni_Hills_Forest_strategic_Ecosystem_Management_Plan_2015 -2040 .

[12] Kiptum, Y. and Odhiambo, C. (2008). Safeguarding Sengwer Territory, Land, Culture \& Natural Resources. Participatory 3Dimensional Modeling of Cherangany Hills. p.2. 
[13] CIFOR. (2013). Forests, food and livelihoods: What policymakers should know. Bogor, Indonesia: Center for International Forestry Research (CIFOR).

[14] Githiomi, J., \& Oduor, N. (2013). Strategies for Sustainable Wood fuel Production in Kenya. International Journal of Applied Science and Technology. Vol. 2 No. 10; December 2012.Retrieved on 31/05/2018 from https://www.researchgate.net/publication/283485457_Strategies _for_Sustainable_Wood_fuel_Production_in_Kenya.

[15] Langat, D. K., Maranga, E. K., Aboud, A. A., \& Cheboiwo, J. K. (2016). Role of Forest Resources to Local Livelihoods: The Case of East Mau Forest Ecosystem, Kenya, 2016. International Journal of Forestry Research Volume 2016, Article ID 4537354,10 pages http://dx.doi.org/10.1155/2016/4537354.

[16] Convention on Biological Diversity. (2008). Forest biodiversity: More than just trees. Paper presented at the Ninth meeting of the Conference of the Parties to the Convention on Biological Diversity, Bonn, Germany.

[17] Rasolofoson, R. A., Ferraro, P. J., Jenkins, C. N., \& Jones, J. P. G. (2015). Effectiveness of Community Forest Management at reducing deforestation in Madagascar. Biological Conservation, 184, 271-277. https://doi.org/10.1016/j.biocon.2015.01.027.

[18] Prasad, N., Dfid, Y., Prakash, O., Dfid, D., Anglia, E., Email, U. K., \& Email, U. K. (2003). Forest Management and Utilization Under Community, Journal of Forest and Livelihood 3 (1), 37-50.
[19] Government of Kenya. (2014). Forest policy, 2014. Government Printers, Nairobi, Kenya.

[20] Mamo, G., Sjaastad, E. and Vedeld, P. (2007). "Economicdependence on forest resources: a case from Dendi District, Ethiopia,"Forest Policy and Economics, vol.9, no.8, pp.916-927.

[21] Ochieng, R. (2009). A Review of degradation status of the Mau Forest and Possible Remedial Measures, Munich, GRIN Verlag, http://www.grin.com/en/e-book/156873/a-review-ofdegradation-status-of-the-mau-forest-and-possible-remedial.

[22] Ngendakumana, S., Bachange, E. G., Damme, P. Van, Speelman, S., Tchoundjeu, Z., Kalinganire, A., \& Bandiaky, S. B. (2013). Rethinking Rights and Interests of Local Communities in REDD + Designs: Lessons Learnt from Current Forest Tenure Systems in Cameroon, ISRN Forestry Volume 2013, Article ID 830902, 14pages http://dx.doi.org/10.1155/2013/830902.

[23] United Nations Conference on Environment and Development. (1992). Agenda 21, Rio Declaration on Environment and Development. United Nations. Retrieved on 25/05/2018 http://www.un.org/documents/ga/conf151/aconf151261annex1.htm.

[24] Persha, L., Agrawal, A. \& Chhatre, A., (2011). Social and ecological synergy: local rulemaking, forest livelihoods, and biodiversity conservation. Science 331, 1606-1608. 